\title{
Plant- and microbial-based mechanisms to improve the agronomic effectiveness of phosphate rock: a review
}

\author{
MELISSA M. ARCAND and KIM D. SCHNEIDER \\ Department of Land Resource Science, University of Guelph, Guelph, Ontario, Canada N1G 2W1 \\ Manuscript received on September 29, 2005; accepted for publication on March 13, 2006; \\ presented by OTHON H. LEONARDOS
}

\begin{abstract}
Deficiency in plant-available phosphorus is considered to be a major limiting factor to food production in many agricultural soils. Mineral resources are necessary to restore soil phosphorus content. In regions where conventional fertilizers are not used due to cost limitations or to mitigate adverse environmental effects, local sources of phosphate rock are being increasingly recognized for potential use as alternative phosphorus fertilizers. The main obstacle associated with using directly applied ground phosphate rock is that the phosphate released is often unable to supply sufficient plant-available phosphorus for crop uptake. Plantand microbial-based mechanisms are low-cost, appropriate technologies to enhance the solubilization and increase the agronomic effectiveness of phosphate rock. Common mechanisms of phosphate rock dissolution including proton and organic acid production will be reviewed for both plants and microorganisms. This review will also address possibilities for future research directions and applications to agriculture, as well as highlight ongoing research at the University of Guelph, Guelph, Canada.
\end{abstract}

Key words: agriculture, microorganisms, phosphate rock, phosphorus, rhizosphere, solubilization.

\section{INTRODUCTION}

Phosphorus $(\mathrm{P})$ deficiencies are limiting crop production in many agricultural soils worldwide where conventional fertilizers are inaccessible. Of total soil $\mathrm{P}$, only 1 to $5 \%$ is in a soluble, plant-available form (Molla and Chowdhury 1984). In sub-Saharan Africa and in similar tropical soils, $\mathrm{P}$ deficiency is considered to be one of the main biophysical constraints to food production (Chien and Menon 1995, Sale and Mokwunye 1993, Sanchez et al. 1997). This deficiency is a result of low inherent P fertility due to weathering, in combination with intensive, nutrient-extracting agricultural practices (Sanchez et al. 1997, Ssali et al. 1986). Additionally, phos-

Correspondence to: Kim D. Schneider

E-mail: kschne01@auoguelph.ca phate diffusion to plant roots may be too low to meet the needs of the crop if soils have low P solubility and/or a high P fixation capacity (Gerke 1992, Hoberg et al. 2005, Sale and Mokwunye 1993). In regions where soils are high in total $\mathrm{P}$, including some temperate soils, deficiencies may also occur if soluble forms of $\mathrm{P}$ are not replenished following plant uptake of $\mathrm{P}$ from soil solution. For example, organically managed soils have been found to become deficient in plant-available $\mathrm{P}$ over the long term without external inputs P (Entz et al. 2001, Oehl et al. 2002). The use of conventional P fertilizers is highly limited in developing regions due to cost (Sagoe et al. 1998a) and is prohibited for use by organic farmers. As a result, locally available sources of phosphate rock (PR) are increas- 
ingly recognized as potential $\mathrm{P}$ fertilizers (Goenadi et al. 2000, Haynes 1992).

The $\mathrm{P}$ released from directly applied ground PR is often too low to provide sufficient $\mathrm{P}$ for crop uptake (Vassilev et al. 2001). Low-technology alternatives to the energy intensive and costly methods of conventional $\mathrm{P}$ fertilizer production have been proposed including enhancing plant and microbiological mechanisms that promote PR solubilization (for extensive reviews see Gyaneshwar et al. 2002, Richardson 2001, Trolove et al. 2003). This paper will review the literature on plant and microbial solubilization of PR, focusing on proton and organic acid production as mechanisms of dissolution, as well as discuss potential applications to agriculture.

\section{SOIL PHOSPHORUS}

The soil $\mathrm{P}$ cycle is a dynamic process involving the transformation of $\mathrm{P}$ by geochemical and biological processes. Plant-available $\mathrm{P}$ occurs in the soil solution as orthophosphate anions, predominantly $\mathrm{H}_{2} \mathrm{PO}_{4-}$ and $\mathrm{HPO}_{4}^{2-}$. Solid inorganic and organic forms of $\mathrm{P}$ are found in labile and poorly soluble forms in the soil, and as a result, can replenish plantavailable $\mathrm{P}$ with varying degrees of effectiveness. Plant-available $\mathrm{P}$, or solution $\mathrm{P}$, is in equilibrium with a relatively labile fraction of $\mathrm{P}$ that is adsorbed to aluminum or ferric hydrous oxides, clays, calcium carbonates and organic matter (i.e. is associated with the solid phase of the soil) (Pierzynski et al. 1994, Whitelaw 2000). As a result, solution $\mathrm{P}$ is easily replenished in response to plant uptake through desorption of $\mathrm{P}$ from the labile solid fraction (Cole et al. 1977, Whitelaw 2000). However, only a small fraction of $\mathrm{P}$ in the solid phase remains in a labile form, as it can become strongly adsorbed to the soil or participate in precipitation reactions. $\mathrm{P}$ may become strongly fixed and eventually precipitate as variscite and strongite in acid soils, or with $\mathrm{Ca}^{2+}$ in alkaline soils (Whitelaw 2000). The effects of $\mathrm{P}$ precipitation are significant in acidic soils, where twice the amount of added $P$ per unit surface area is fixed compared to neutral or calcareous soils (Whitelaw 2000).
The organic $\mathrm{P}$ pool generally constitutes 30 to $80 \%$ of the total soil $\mathrm{P}$ (Oberson et al. 1996) and represents a labile $\mathrm{P}$ fraction that may supply $\mathrm{P}$ to plants through mineralization by the microbial biomass (Stewart and Tiessen 1987). The microbial biomass is a small fraction of the total soil organic $\mathrm{P}$, containing anywhere between 3 to $24 \%$ depending on cultivation (Brookes et al. 1984). However, it is significant in its role as recycler of $\mathrm{P}$ and as a relatively labile P source (Kwabiah et al. 2003).

$\mathrm{P}$ loss through crop removal can significantly reduce the soluble and labile $\mathrm{P}$ in the soil and decrease total soil $\mathrm{P}$ without external inputs. The addition of PR will increase total soil $\mathrm{P}$ with the potential to replenish labile $\mathrm{P}$ and plant-available $\mathrm{P}$. By utilizing plant and microbial mechanisms that can effectively extract $\mathrm{P}$ from PR and release it into the soil solution or into the labile fraction of the soil, PR resources may provide a viable alternative for $\mathrm{P}$ fertilization.

\section{Solubilization of Phosphate Rock}

PR may originate from igneous, sedimentary, metamorphic, and biogenic sources, with sedimentary being the most widespread (van Straaten 2002). Forms of apatite, the primary $\mathrm{P}$ bearing mineral in PR, include fluorapatite, hydroxyapatite, carbonatehydroxyapatite, and francolite (van Straaten 2002). In general, high carbonate-substituted forms of apatite (francolite) will solubilize more readily than pure forms of fluorapatite, releasing more $\mathrm{P}$ for plant use (Anderson et al. 1985). In addition to PR source, the major influences on PR solubility are soil properties, crop species, and management practices (Chien and Menon 1995). These factors have various influences on the equilibrium of the dissolution reaction of a given apatite mineral. A simplified dissolution equation is shown in Equation 1 .

$$
\begin{aligned}
& \mathrm{Ca}_{10} \mathrm{~F}_{2}\left(\mathrm{PO}_{4}\right)_{6}+12 \mathrm{H}^{+} \\
& \quad \rightarrow 10 \mathrm{Ca}^{2+}+6 \mathrm{H}_{2} \mathrm{PO}_{4^{-}}+2 \mathrm{~F}^{-}
\end{aligned}
$$

Engelstad et al. (1974) found that the lower the soil $\mathrm{pH}$, the more available the $\mathrm{P}$ from PR becomes. 
Moreover, since apatite dissolution releases $\mathrm{Ca}^{2+}$, soils high in calcium do not support PR dissolution, in accordance with the mass action law (Chien and Menon 1995). Similarly, the dissolution of PR will be favored if $\mathrm{Ca}^{2+}$ is removed from soil solution (Flach et al. 1987).

Plant And Microbial Mediated PR SolubilizaTION

Certain plant species exhibit mechanisms localized in the rhizosphere that allow for the efficient use of $\mathrm{P}$ through the dissolution of PR. Bolan et al. (1997) found that PR dissolved more efficiently in the presence of plants than in the absence of plants. In addition, it is well known that the effect of PR on plant growth varies among species (Flach et al. 1987). Non-mycorrhizal plants, including those in the Cruciferae family or plants such as white lupin (Lupinus albus L.) that form root clusters, have been found to effectively utilize $\mathrm{P}$ from PR particularly when soils are deficient in $\mathrm{P}$ or in response to Al toxicity. Similarly, certain microorganisms are capable of solubilizing PR and are collectively termed phosphate-solubilizing microorganisms (PSM). Rhizobacteria, from the genera Pseudomonas, Bacillus, and Rhizobium, are among the most powerful phosphate solubilizing bacteria (Rodriguez and Fraga 1999). In contrast, it has commonly been observed that certain filamentous fungi, predominantly Penicillium and Aspergillus species, have greater phosphate-solubilizing ability than many bacteria in both liquid and solid media (Banik and Dey 1982, Gaur et al. 1973, Kucey 1983). Mycorrhizal fungi have also been shown to increase P uptake (Barea et al. 2002, Bolan 1991, Thingstrup et al. 2000, Trolove et al. 2003), but a discussion on this topic is beyond the scope of this paper. For both plants and microorganisms, the two primary mechanisms attributed to solubilization of $\mathrm{PR}$ are $\mathrm{H}^{+}$excretion and organic acid production.

\section{$\mathrm{H}^{+}$Excretion ANd PR Dissolution}

Excretion of $\mathrm{H}^{+}$by plant roots into the rhizosphere is caused by a higher uptake of cations relative to anions. Plants that exhibit an alkaline uptake pattern, i.e. higher uptake of cations to anions, will cause $\mathrm{pH}$ changes by exuding $\mathrm{H}^{+}$from their roots to maintain a narrow $\mathrm{pH}$ range, roughly 7.3 , in the cytosol (Bekele et al. 1983, Hinsinger et al. 2003). Buckwheat (Fagopyrum esculentum) has been found to exhibit a strong alkaline uptake and $\mathrm{H}^{+}$release pattern compared to other plant species, and additionally, has demonstrated high $\mathrm{Ca}^{2+}$ uptake, which also contributes to PR dissolution (Bekele et al. 1983). In a pot study comparing the ability of buckwheat, maize (Zea mays L.), wheat (Triticum aestivum L.), and two species of grass to utilize $\mathrm{P}$ from various forms of PR, a strong negative correlation $(r=-0.883)$ between the cation to anion uptake ratio of buckwheat and soil $\mathrm{pH}$ was found. The rhizosphere $\mathrm{pH}$ change induced by buckwheat was significantly greater than the $\mathrm{pH}$ change caused by the other plants (van Ray and van Diest 1979). In a different study, buckwheat and white lupin exhibited a higher cation to anion uptake ratio and significantly lowered rhizosphere $\mathrm{pH}$ when compared to wheat, barley (Hordeum volgare L.), kale (Brassica oleracea), and rape (Brassica napus) (Haynes 1992).

Plant supply of nitrogen (N) can have a measurable effect on $\mathrm{pH}$ change, as $\mathrm{H}+$ ions are released from the roots during the assimilation of ammonium $\left(\mathrm{NH}_{4}^{+}\right)$. The cation to anion uptake ratio will increase for plants that rely on $\mathrm{NH}_{4}^{+}$rather than nitrate $\left(\mathrm{NO}_{3^{-}}\right)$, decreasing rhizosphere $\mathrm{pH}$. Gahoonia et al. (1992) found that the rhizosphere $\mathrm{pH}$ of ryegrass (Lolium perenne cv 'Printo') decreased by 1.6 units when fertilized with $\mathrm{NH}_{4}^{+}$, while $\mathrm{pH}$ increased by 0.6 units when fertilized with $\mathrm{NO}_{3^{-}}$. Similarly, soil $\mathrm{pH}$ decreased when maize (Zea mays L.) was supplied with $\mathrm{NH}_{4}^{+}$compared to $\mathrm{NO}_{3^{-}}$(Flach et al. 1987). Soil P depletion by ryegrass, which was correlated with $\mathrm{P}$ uptake, also increased significantly with $\mathrm{NH}_{4}^{+}$fertilization compared to the $0 \mathrm{~N}$ and $\mathrm{NO}_{3}$ - controls (Gahoonia et al. 1992). Buckwheat $P$ uptake was also improved with $\mathrm{NH}_{4}^{+}$compared to $\mathrm{NO}_{3}$ - fertilization (Zhu et al. 2002). Leguminous plants, which fix 
atmospheric $\mathrm{N}$, require little $\mathrm{N}$ in the form of nitrate; as a result, they take up more cations than anions, contributing to $\mathrm{H}^{+}$release (Hinsinger et al. 2003, Weil 2000). Nitrification may also result in acidification; however this effect is often negated by increased plant uptake of $\mathrm{NO}_{3^{-}}$anions, resulting from nitrification (Bekele et al. 1983). Finally, while $\mathrm{NH}_{4}^{+}$fertilization may lower the soil $\mathrm{pH}$, Flach et al. (1987) found that $\mathrm{NO}_{3}$ - fertilization promoted $\mathrm{Ca}^{2+}$ uptake by pearl millet (Pennisetum typhoides) and finger millet (Elusine coraca$n a$ ), which shifted the mass equilibrium to favor PR dissolution.

Similar to plants, microbial excretion of $\mathrm{H}^{+}$ occurs in response to the assimilation of cations, primarily related to $\mathrm{N}$ source. It is a well-known fungal phenomenon that $\mathrm{H}^{+}$is excreted in exchange for $\mathrm{NH}_{4}^{+}$(Asea et al. 1988, Banik and Dey 1982, Beever and Burns 1980). Using laboratory media, it has been observed that more PR is solubilized when using an $\mathrm{NH}_{4}^{+}$rather than a $\mathrm{NO}_{3}$ - source of $\mathrm{N}$ (Whitelaw et al. 1999). In the same study, it was found that $\mathrm{pH}$ was generally lower and titratable acidity higher, when $\mathrm{NH}_{4}^{+}$was used. Similarly, Vora and Shelat (1998) tested a variety of N sources and found that ammonium sulphate promoted the most PR solubilization for bacterial species, Bacillus circulans, Bacillus brevis, and Bacillus coagulans. For some microorganisms, the release of $\mathrm{H}^{+}$ ions due to the assimilation of $\mathrm{NH}_{4}^{+}$seems to be the sole mechanism promoting PR dissolution. For example, in an experiment by Asea et al. (1988), the fungi Penicillium bilaii and Penicillium fuscum were tested for their ability to solubilize PR on two different media: one containing $\mathrm{NH}_{4}^{+}$and another without $\mathrm{N}$. In the $\mathrm{NH}_{4}^{+}$medium, both species were able to decrease $\mathrm{pH}$ and solubilize PR; however, in the absence of N, only P. Bilaii maintained the ability to lower the $\mathrm{pH}$ and solubilize PR. The latter results indicate that different mechanisms were utilized by the different species; one mechanism required the presence of $\mathrm{NH}_{4}^{+}$in the medium and the other did not. The amount of $\mathrm{P}$ solubilized by P. Fuscum was found to be directly related to
$\mathrm{pH}$, while $P$. Bilaii solubilized more PR than could be accounted for by the $\mathrm{pH}$ change, indicating that another mechanism, in addition to $\mathrm{H}^{+}$production, was contributing to PR solubilization. Other authors have found no correlation between the amount of PR solubilized and the $\mathrm{pH}$, supporting the fact that an alternative mechanism of solubilization exists (Cerezine et al. 1988, Sperber 1958a, Whitelaw et al. 1999, Sagoe et al. 1998b).

\section{ORganic ACID Production AND PR Dissolution}

Both plants and microorganisms are known to produce organic acids in varying concentrations and types. Commonly reported organic acids produced by microorganisms include gluconic, citric and oxalic acids (Richardson 2001), while plants most commonly produce citric, oxalic, and malic acids (Jones 1998, Ryan et al. 1995, Zheng et al. 2005). The ability of organic acids to solubilize phosphate rock is attributed to the following mechanisms: acidification, chelation, and exchange reactions (Omar 1998).

\section{Acidification}

Organic acids contribute to the lowering of solution $\mathrm{pH}$ as they dissociate in a $\mathrm{pH}$ dependent equilibrium, into their respective anion(s) and proton(s). As discussed previously, $\mathrm{H}^{+}$ions favor PR solubilization by shifting the equilibrium of the dissolution equation (Equation 1), subsequently releasing more $\mathrm{P}$ into solution. Organic acids buffer solution $\mathrm{pH}$ and will continue to dissociate as protons are consumed by the dissolution reaction (Welch et al. 2002). Although organic acids are present in soil, plant-induced dissolution of PR is predominantly a result of organic acid anion extrusion (Hinsinger 2001, Hinsinger et al. 2003, Jones 1998); therefore, the discussion of plant-induced acidification will focus on organic acids in their fully dissociated form as anions (herein referred to as organic acid anions). Similarly, microorganisms often export organic acids as anions (Duro and Serrano 1981, Konings 1985, Netik et al. 1997), which must be 
actively transported across the plasma membrane (Stein 1967). The export of organic acid anions by fungi can occur by an $\mathrm{H}^{+}$-symport transport system, causing acidification of the external solution (Netik et al. 1997).

Studies involving plant uptake of $\mathrm{P}$ from PR have assumed that exudation of organic acids from plant roots cause direct acidification of the rhizosphere (Chien et al. 2003, Hoffland et al. 1989b, Mnkeni et al. 2000). Since the $\mathrm{pH}$ of plant cytosol is around 7.1 to 7.4 (Hinsinger 2001) citrate, malate and oxalate, organic acids predominantly found in plants (Jones and Darrah 1994), are present in their fully dissociated form as citrate ${ }^{3-}$, malate ${ }^{2-}$, and oxalate $^{2-}$ and, as such, organic anions, not acids, are exuded by plants (Hinsinger et al. 2003, Jones 1998). Counter-ions will often accompany the release of an organic acid anion in order to maintain electrical neutrality, which can lead to acidification of the rhizosphere in some cases, but not all (Jones 1998). In certain plant species, such as white lupin, exudation of organic acid anions will result in acidification of the rhizosphere through the simultaneous release of $\mathrm{H}^{+}$(Dinkelaker et al. 1989). Other counter-ions have also been associated with the release of organic acid anion exudation. For example, $\mathrm{K}^{+}$was released with malate in Al-tolerant wheat, resulting in no change in rhizosphere $\mathrm{pH}$ (Ryan et al. 1995). Finally, a counter-cation may not be released with the organic acid anion; instead, $\mathrm{OH}^{-}$ may be taken up by the plant to maintain electroneutrality, ultimately resulting in rhizosphere acidification (Hinsinger et al. 2003). The acidification that occurs as a result of organic acid anion extrusion by plants is related to the overall cation to anion balance as previously discussed (Durand et al. 2001).

The extent of acidification in the rhizosphere due to organic acid anion release is dependent on plant species. For example, in a review of the literature, Hinsinger et al. (2003) found that organic acid anions exuded from maize contributed at most, $0.3 \%$ to rhizosphere acidification, while white lupins were found to exude citrate accompanied by
$\mathrm{H}^{+}$in quantities high enough to lower the rhizosphere pH from 7.5 to 4.8 (Dinkelaker et al. 1989). Rape, which has been shown to exude malate and citrate (Hoffland et al. 1989b), exhibited a decrease in rhizosphere $\mathrm{pH}$ from 6.5 to 4.1 in a pot study where $\mathrm{NO}_{3^{-}}$was the sole $\mathrm{N}$ source (Grinsted et al. 1982); however, Haynes (1992) found a rise in rhizosphere $\mathrm{pH}$, even with $\mathrm{NH}_{4}^{+}$fertilization. Hedley et al. (1982) found that rape exhibited an alkaline uptake pattern, which corresponded to a decrease in rhizosphere $\mathrm{pH}$ and found no significant amount of low-molecular organic acid anions in the rhizosphere. In contrast, subsequent studies by Bekele et al. (1983), Hoffland et al. (1989a) and Chien et al. (2003) showed that rape did not exhibit an alkaline uptake pattern, suggesting that high $\mathrm{Ca}^{2+}$ uptake and exudation of organic acid anions may have resulted in increased P uptake from PR (Bekele et al. 1983, Haynes 1992, Hoffland 1992). Moreover, the ability of rape to utilize $\mathrm{P}$ from $\mathrm{PR}$ may be independent of $\mathrm{pH}$ changes in the rhizosphere (Haynes 1992), and therefore may be due to other processes occurring in the soil.

\section{Chelation}

In addition to $\mathrm{pH}$ reduction, organic acid anions can solubilize PR through chelation reactions. Chelation involves the formation of two or more coordinate bonds between an anionic or polar molecule and a cation, resulting in a ring structure complex (Whitelaw 2000). Organic acid anions, with oxygen containing hydroxyl and carboxyl groups, have the ability to form stable complexes with cations such as $\mathrm{Ca}^{2+}, \mathrm{Fe}^{2+}, \mathrm{Fe}^{3+}$, and $\mathrm{Al}^{3+}$, that are often bound with phosphate in poorly forms (Jones 1998, Kucey 1988). By complexing with cations on the mineral surface, organic acid anions loosen cation-oxygen bonds of the mineral structure and catalyze the release of cations to solution (Welch et al. 2002). Organic acid anions continue to alter the equilibrium of the dissolution reaction by complexing with cations in solution, effectively lowering the solution saturation point (Welch et al. 2002). 
Results from a study by Kpomblekou-A and Tabatabai (1994) show that the ability of organic acids to solubilize PR is affected by the chemical structure, as well as the type and position of functional groups of the organic ligand. These results are further supported by Narsian and Patel (2000), who tested the effects of known chelators including EDTA, DTPA, NTA, aluminon, and oxine, on PR solubilization. This study concluded that PR solubilization was related to the functional groups of the chelators, particularly carboxylic and phenolic hydroxyls. The formation of complexes between chelator and cations such as $\mathrm{Al}^{3+}$ and $\mathrm{Ca}^{2+}$ depends on the number and kind of functional groups involved as well as the specific cation. It has been found that acids with an increased number of carboxyl groups are more effective at solubilizing PR (Xu et al. 2004, Kpomblekou-A and Tabatabai 1994). For example, $\mathrm{Ca}^{2+}$ was found to form complexes more readily with tricarboxylic acids such as citric acid, over dicarboxylic acids such as malic and tartaric acids (Whitelaw 2000). An increased number of hydroxyl $\left(\mathrm{OH}^{-}\right)$groups has a positive effect on the ability of an organic acid anion to dissolve PR, and a-substitution seems to enhance this effect (Johnston 1954, Kpomblekou-A and Tabatabai 1994).

Citric acid, a tricarboxylic acid with one $\alpha$ - and two $\beta$-substituted hydroxyl groups, has shown to be superior to other acids in its PR solubilizing ability (Kpomblekou-A and Tabatabai 1994, Xu et al. 2004). Penicillium bilaii, a significant citric acid producer, has shown to be an effective PR solubilizer (Cunningham and Kuiack 1992, Kucey 1988). In addition, Aspergillus niger, used in the industrial production of citric acid, has been recognized as one of the most effective organisms for PR solubilization (Abd-Alla and Omar 2001, Agnihotri 1970, Omar 1998, Sperber 1958b). Tricarboxylic acids are not always superior to dicarboxylic acids in PR solubilizing ability; Sagoe et al. (1998b) found oxalic and tartaric acids, which are dicarboxylic acids, release more $\mathrm{P}$ into solution than citric acid. This exception was attributed to the fact that oxalic and tartaric acids form poorly soluble precipitates with $\mathrm{Ca}^{2+}$, effectively lowering the solution saturation point (Sagoe et al. 1998b).

\section{Ligand exchange reactions}

Lastly, through competition with phosphate anions that are adsorbed to crystalline $\mathrm{Fe}(\mathrm{OH})_{3}$ and $\mathrm{Al}(\mathrm{OH})_{3}$ surfaces, organic acid anions can contribute to $\mathrm{P}$ mobilization through ligand exchange reactions (Gahoonia et al. 1992, Jones 1998, Trolove et al. 2003). In a study using four soils of varying $\mathrm{pH}, \mathrm{CaCO}_{3}$ and organic $\mathrm{C}$ contents, Gerke et al. (2000) found that in all soils more $\mathrm{P}$ was mobilized when citrate was added than when the soil was subjected to a wide range of $\mathrm{pH}$ changes. This finding indicated that the $\mathrm{P}$ was mobilized due to ligand exchange between the citrate and the phosphate adsorbed to the $\mathrm{Fe}$ - and $\mathrm{Al}$ - sites rather than dissolution from Ca-P precipitates (Gerke et al. 2000). In soil, citrate may mobilize phosphate when it is adsorbed at levels greater than $10 \mathrm{~mol} \mathrm{~g}^{-1}$ soil; however below this critical value, citrate will not out-compete phosphate for soil adsorption sites (Gerke et al. 2000). In cases where plants are able to exude sufficient organic acid anions to compete for adsorption sites, they may be suitable for PR solubilization; however, beyond plant species such as white lupin, red clover, or rape, most plants cannot achieve these levels (Hinsinger 2001).

\section{Organic acids in soils}

The fate of organic acid anions released into the rhizosphere by plants is influenced by soil factors. Relative to inorganic ions such as $\mathrm{Ca}^{2+}, \mathrm{NO}_{3^{-}}, \mathrm{K}^{+}$, $\mathrm{Cl}^{-}, \mathrm{Na}^{+}$, and $\mathrm{Mg}^{+}$, organic acid anions are found in soil at very low and near constant concentrations (Jones et al. 2003). Soil has a very high affinity for organic acid anions, particularly di- and tricarboxylic anions, which keep soil solution concentrations low (Jones et al. 2003). Darrah (1991) found that $99 \%$ of ${ }^{14} \mathrm{C}$-labeled citrate was associated with the soil solid phase, indicating that it had been adsorbed by soil colloids. Soil $\mathrm{pH}$ and the 
charge carried on the organic acid will determine how strongly the anion will adsorb to the soil, with the greatest adsorption occurring for citrate (Jones et al. 2003). If adsorbed to $\mathrm{Fe}$ and $\mathrm{Al}$ hydroxides, almost no biodegradation of citrate will occur; however, soil microbial mineralization of organic acids has been found to be rapid in the rhizosphere and soils high in organic matter (Jones 1998). Therefore, the exudation of citrate and possibly other organic acid anions into the soil solution may not actively promote PR dissolution as effectively as in liquid medium studies.

\section{APPlication of Plants In PR Dissolution}

Certain plant species have shown positive response to PR fertilization when tested against fertilization without PR. Response has been measured in terms of $\mathrm{P}$ uptake, plant tissue $\mathrm{P}$, and yield (Chien et al. 2003, Haynes 1992, Mnkeni et al. 2000). Rape has been shown by a number of authors to effectively utilize PR (Chien et al. 2003, Hoffland et al. 1989a). Mnkeni et al. (2000) found that a low reactive igneous PR from Tanzania was half as effective as TSP at improving rape yield in an alkaline soil. However, Chien et al. (2003) found that rape yield was not improved when using the same PR also in an alkaline soil, possibly due to a greater application rate of the PR in the former study. In another study, Haynes (1992) found that rape dry yield and aboveground tissue $P$ content were higher when fertilized by North Carolina PR than the soluble fertilizer, monocalcium $P$.

Buckwheat has been found to utilize PR through an alkaline uptake pattern, as well as high $\mathrm{Ca}^{2+}$ uptake (Flach et al. 1987, van Ray and van Diest 1979). As a result, buckwheat has potential for use in calcareous soils. In a greenhouse study, a strong positive correlation $(r=0.893)$ was found between the cation to anion uptake ratio and $\mathrm{P}$ uptake of buckwheat from PR, where the authors compared $\mathrm{P}$ utilization of six plant species from five PR sources (van Ray and van Diest 1979). In a pot experiment, using a calcareous field soil and a sandy soil, Zhu et al. (2002) examined the P uptake effi- ciency of buckwheat and wheat grown with North Carolina PR and $\mathrm{CaHPO}_{4}$. For both $\mathrm{P}$ sources, buckwheat tissue $\mathrm{P}$ and $\mathrm{P}$ uptake were higher than those of wheat when grown in the sandy soil $(\mathrm{pH}$ 6.5). Buckwheat tissue $P$ was not significantly different when grown with nitrate or ammonium, despite the fact that fertilization by nitrate or ammonium would likely result in different rhizosphere pH (Zhu et al. 2002).

Potential applications for the plant-induced dissolution of PR include the combined use of PR with the planting of a green manure crop. Plants grown as green manures that are capable of extracting $\mathrm{P}$ from $\mathrm{PR}$ have the potential to supply $\mathrm{P}$ to a subsequent crop through organic $\mathrm{P}$ mineralization (Stewart and Tiessen 1987). In a field study, McLenaghen et al. (2004) found that maize yield and $P$ uptake increased with the combined application of PR and planting of lupin (Lupinus angustifolius, cv. Fest), whereas maize yield was unaffected when either lupin, as a green manure crop, or PR was used alone. These results indicate that despite the ability of lupin to extract $P$ from otherwise unavailable native $\mathrm{P}$ sources, it was the presence of PR grown together with the green manure that caused a positive effect on the $\mathrm{P}$ uptake of maize (McLenaghen et al. 2004). However, in a greenhouse study, Cavigelli and Thien (2003) found that P uptake by sorghum (Sorghum bicolor (L.) Moench) following incorporation of white lupin, was lower than that of other crops including the control with no cover crop, despite the fact that $\mathrm{P}$ uptake by white lupin was two to three times greater than pea, hairy vetch, and winter wheat (Cavigelli and Thien 2003). The authors suggested that the reduced $P$ uptake of sorghum, following white lupin incorporation, was attributed to suppressed mycorrhizal formation, since white lupin is nonmycorrhizal. The authors also found that white lupin was capable of extracting soil $\mathrm{P}$ from fractions more low soluble than what could be extracted from Bray-1 (plantavailable P) extracts. Therefore, they concluded that the $\mathrm{P}$ released during decomposition of white lupin might have sorbed back to forms unavailable 
to sorghum (Cavigelli and Thien 2003). Additionally, factors affecting the mineralization of organic $\mathrm{P}$ from plant residues, particularly microbial activity will determine how well $\mathrm{P}$ will be supplied to plants following incorporation of P-loaded green manures (Oehl et al. 2004). As such, inorganic and organic cycles of $\mathrm{P}$ must be considered when examining the combined use of PR and a green manure crop.

\section{APPLICATION OF PSM IN PR DisSOLUTION}

Field inoculation in combination with direct application of $P R$

Traditionally, most experiments using PSM have employed two major strategies for increasing $\mathrm{P}$ availability from PR: the management of existing soil microbial populations to optimize their capacity to mobilize $\mathrm{P}$, and the development of specific microbial inoculants (Richardson 2001). Although there have been some successful results from soil inoculations of PSM (Kucey 1987, Kucey and Leggett 1989, Omar 1998, Asea et al. 1988), in general, the results in terms of plant growth and crop yields, have been highly variable (Gyaneshwar et al. 2002). Organisms that can effectively solubilize PR in the laboratory, under controlled conditions, may be unable to do so in the field (Richardson 2001). These variations in effectiveness may be due to the reduced ability of inoculated PSM to survive and colonize the rhizosphere, coupled with competition for resources with native soil microorganisms (Gyaneshwar et al. 2002). In a study by Dwivedi et al. (2004), it was found that the inoculation of Aspergillus awamori to wheat and rice seedlings, increased the crop response to Musoorie PR over the non-inoculated treatments, but was not statistically significant. It was suggested that possible reasons for this outcome could be that soil organic carbon levels were very low and that temperature fluctuations were not ideal for enhanced PSM activity (Dwivedi et al. 2004).

\section{Microbial treatment of $P R$ before application to the field}

High carbon crop wastes have been suggested for use as fermentation substrates in the microbial solubilization of PR before application to the field (Nahas et al. 1990, Vassilev et al. 1995, Vassilev et al. 1996). This method has the advantage of creating more optimal conditions for microbial organic acid production compared with conditions present in soil. For example, A. niger requires an excessive carbon source and suboptimal concentrations of nitrogen and many trace metals, to achieve maximal citric acid production (Grewal and Kalra 1995, Karaffa and Kubicek 2003). In a pot trial, using Grenada (Spain) soil, Vassilev et al. (1996) studied the effect of adding sugar beet (SB) (Beta vulgaris) waste, pre-cultured with A. niger in the presence of Moroccan PR, on the growth of white clover (Trifolium repens). The pretreatment of $\mathrm{PR}$ with the inoculated SB waste significantly improved crop dry weight and shoot $\mathrm{P}$ content compared to plants given the same amount of untreated PR and SB waste. In another pot trial, using the same soil and PR, Rodriguez et al. (1999) found similar results in an experiment measuring the yield of alfalfa (Medicago sativa L. cv Aragon). When PR was pre-incubated with A. niger inoculated SB waste, alfalfa dry matter yield increased significantly compared to the treatment that received non-inoculated SB residue and PR. Vassileva et al. (1998a) pretreated Moroccan PR with A. niger inoculated olive cake-based medium, before application to greenhouse pots containing P-deficient calcareous soil. It was found that white clover shoot dry weight and $\mathrm{P}$ content was significantly higher in the pots that received pretreated PR compared to the control that received untreated PR and olive cake waste. The authors stated that it appeared "the preincubation of the waste material is the key factor in the effectiveness of this system" (Vassileva 1998a). Similar experiments have now been conducted in the field. Alguacil et al. (2003) tested the effect of the combined treatment of SB waste, pretreated with 
A. niger in the presence of Moroccan PR, when trying to revegetate degraded semi-arid land in the Mediterranean with Cistus albidus L. (rock rose shrub). It was found that the fermented SB and RP mixture significantly increased the available $\mathrm{P}$, total $\mathrm{N}$, and extractable $\mathrm{K}$ contents of the soil, with the greatest increase observed in available $\mathrm{P}$ content.

The results of the above studies, with support from the available literature on citric acid production by A. niger (Karaffa and Kubicek 2003), suggest that through an aerobic fermentation process, A. niger converts SB residue, which is high in reducing sugars, to citric and oxalic acids. The organic acids produced by $A$. niger may then increase plant-available $\mathrm{P}$ from $\mathrm{PR}$, effectively enhancing the agronomic effectiveness of the rock. Comparatively, using abiotic organic acids to pretreat PR before application to soil has been explored (Sagoe et al. 1998a). Six different PRs were treated with $1 \mathrm{M}$ oxalic and tartaric acids and applied to pots containing Italian ryegrass (Lolium multiflorum Lam. cv. Tachiwase) in granitic regosol. Plant dry matter yield and $\mathrm{P}$ uptake was significantly increased in pots that received organic acid treated PRs over those that were given untreated PRs (Sagoe et al. 1998a). Furthermore, in situations where soils are sufficient in total $\mathrm{P}$, but $\mathrm{P}$ is predominantly present in poorly soluble complexes, the addition of organic acids to soil may increase phosphate availability without any additional input of P. Gerke (1992) found that additions of citric acid (10-50 $\mu \mathrm{M} \mathrm{g}^{-1}$ soil) increased the solubility of existing P sources in iron and aluminum rich soil. Similarly, the application of $A$. niger fermented sugar beet residue to a cadmium $\left(5 \mu \mathrm{g} \mathrm{g}^{-1}\right)$ artificially contaminated soil, with or without PR, significantly increased P tissue concentration in white clover, compared to the unamended control (Medina et al. 2005). It was also found that plant cadmium uptake decreased significantly in the amended soils, compared to the unamended control, indicating that cadmium was made less plant-available (Medina et al. 2005). Because soils are often buffered against $\mathrm{pH}$ changes, it is likely through the action of chelation and ligand exchange reactions that organic acids are able to increase the availability of labile and low soluble soil P.

Various studies have observed that as the amount of PR added to the microbial fermentation medium increased, the relative percentage of PR solubilized, based on the total amount of PR added, decreased (Nahas et al. 1990, Omar 1998, Asea et al. 1988). Similarly, Vassileva et al. (1998b) found that organic acid production by encapsulated A. niger, decreased as higher amounts of PR were added to the cultivation medium. This observation may be contributed to the rise in $\mathrm{pH}$ that occurs as PR is added to the solution, which would lead to lower yields of citric acid (Vassilev et al. 2001). In addition, citric acid production by $A$. niger decreases as trace metal concentrations, including $\mathrm{Mn}^{2+}, \mathrm{Fe} 2+$, and $\mathrm{Zn}^{2+}$, increase (Grewal and Kalra 1995, Mattey 1992). PR may often be a source of trace metals; as such, the addition of PR to the fermentation medium may actually decrease acid production, and the potential amount of PR solubilized.

Recently, the effects of adding the liquid culture supernatant (LCS), from fermentation media, to PR have been investigated (Goenadi et al. 2000, Widiastuti et al. 2000). The treatment of PR with LCS from A. niger BCCF.194 resulted in significant increases in $2 \%$ citric acid soluble $\mathrm{P}$ content of Moroccan PR (Goenadi et al. 2000). In Indonesia, the use of LCS from A. niger, together with phosphoric acid, is now proposed as a replacement for sulfuric acid in the conventional production of superphosphate fertilizer (Goenadi et al. 2002). An organic acid analysis of the LCS from A. niger Korbe 0909 in Pikovskaya's cultivation medium (Subba Rao 1999) showed the presence of $1334 \mathrm{mg} \mathrm{kg}^{-1}$ oxalic, $326 \mathrm{mg} \mathrm{kg}^{-1}$ citric, $263 \mathrm{mg} \mathrm{kg}^{-1}$ gluconic, and $131 \mathrm{mg} \mathrm{kg}^{-1}$ glycolic acids (Widiastuti et al. 2000). It is not surprising that the ratio of oxalic acid produced to citric acid produced was high, since the medium utilized did not have a high carbon concentration ( $\sim 1 \%$ glucose $)$. By selectively altering the culture conditions, the ratio of citric acid 
to other acids should greatly increase (Karaffa and Kubicek 2003). As citrate is a strong chelator of $\mathrm{Ca}^{2+}$, higher citrate concentrations should have favorable effects on PR solubilization. If PR solubilization is greatly enhanced by organic acids, the use of LCS represents an exciting possibility for the pretreatment of PR before application to soil. Further research is required to compare PR solubilization efficiency of LCS (or fermented crop wastes) with the pretreatment method that includes PR in the fermentation media.

\section{Current Research and Future Outlook}

Through the production of $\mathrm{H}^{+}$ions and organic acid anions, both plants and microorganisms are able to solublize PR. Plants that can mobilize P from PR can be used as green manures by incorporating the plant biomass into the soil. Subsequent mineralization of the plant residue may help replenish both labile and soil solution $\mathrm{P}$, thus making the direct application of PR more agronomically effective. Additionally, optimizing microbial culture conditions, in a controlled environment for organic acid production, may enhance PR dissolution prior to field application. Research designed to further understand the mechanisms behind the biological solubilization of PR will allow these processes to become more efficient, something that is necessary in order to become viable options for restoring soil $\mathrm{P}$ fertility.

In Canada, there is growing concern over possible plant-available $\mathrm{P}$ deficiencies in organically managed soils nationwide (Martin et al. unpublished data). Organic farms are more heavily dependent on on-farm recycling of nutrients in the form of organic amendments (Loes and Ogaard 2001); however Sanchez et al. (1997) state that organic sources of $\mathrm{P}$ are often insufficient in restoring plant-available P. To address this concern, a field study is currently being conducted at the University of Guelph (Canada) to determine the effectiveness of various sources of PR available in North America on the P uptake of buckwheat on calcareous soil. Figure 1 shows preliminary results, which suggest that buckwheat can utilize Calphos, a sedimentary
PR from Florida, USA, as effectively as soluble P fertilizer, TSP at an application rate of $100 \mathrm{~kg} \mathrm{P}$ $\mathrm{ha}^{-1}$ (Arcand et al. unpublished data). Continued work will examine the effectiveness of buckwheat as a green manure crop as determined by Olsen $\mathrm{P}$ and resin $\mathrm{P}$ soil tests, as well as on the P uptake of a subsequent annual ryegrass (Lolium multiflorum) crop.

Further research into the solubilization of $\mathrm{PR}$ in the rhizosphere is necessary. For instance, it is important to elucidate the precise biochemical mechanisms involved in the extraction of $\mathrm{P}$ from $\mathrm{PR}$ in the rhizosphere. The conflicting evidence pertaining to the role and fate of organic acid release into the rhizosphere needs to be examined. Additionally, the majority of studies examining plantinduced dissolution of PR utilize sand or synthetic soil in pot studies, which may not reflect true field soil and weather conditions. The influence of soil factors on the dissolution of PR is inherently important in rhizosphere uptake of P from PR since soil factors influence the diffusion of $\mathrm{P}$ to plant roots. Using 18 different soils, Anderson et al. (1985) found that $75 \%$ of the variability of $\mathrm{P}$ released from $\mathrm{PR}$ was due to soil characteristics including $\mathrm{pH}$, $\mathrm{Ca}^{2+}$ and $\mathrm{H}^{+}$concentrations, buffering capacity, and moisture holding capacity.

The use of organic acid producing PSM in a PR pretreatment process, under controlled conditions, prior to field application, represents a promising low-input and appropriate technology for increasing the agronomic effectiveness of PR. Crop yield and plant tissue $\mathrm{P}$ content values, obtained in previously mentioned greenhouse and field trials, where high carbon crop wastes were used as PSM growth substrates, indicate enhanced PR solubilization occurs through PR pretreatment. These positive results of PR solubilization are supported by Scanning Electron Microscope pictures (Hitachi S-4500) taken of Panda PR (Tanzania) after exposure to $A$. niger inoculated cassava waste (van Straaten unpublished data). Figure $2 \mathrm{a}$ and $\mathrm{b}$ show a PR granule before and after 5 days exposure to the fermenting crop waste. Although not quantitative, these results 


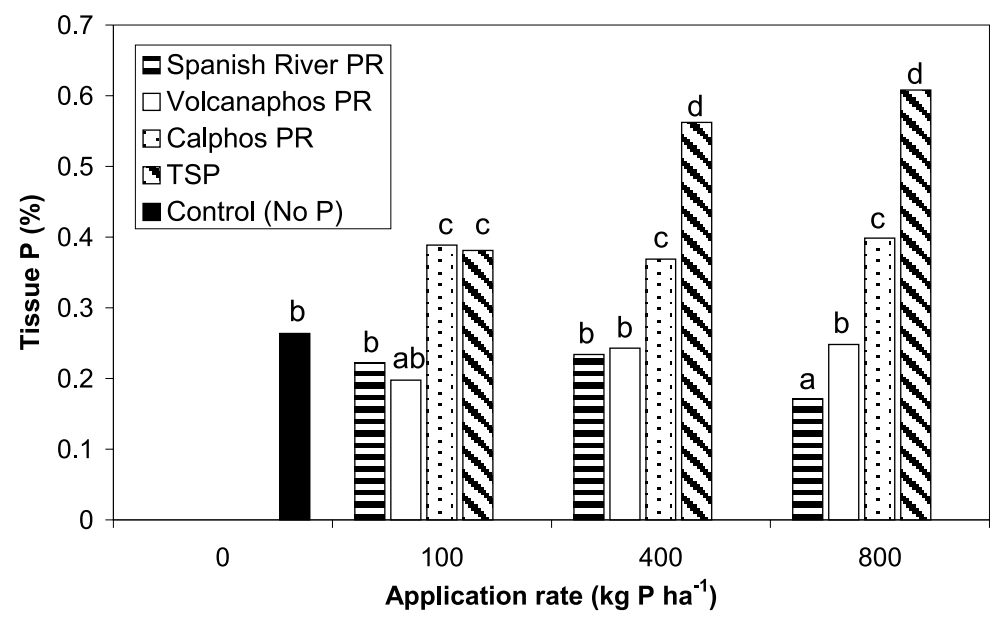

Fig. 1
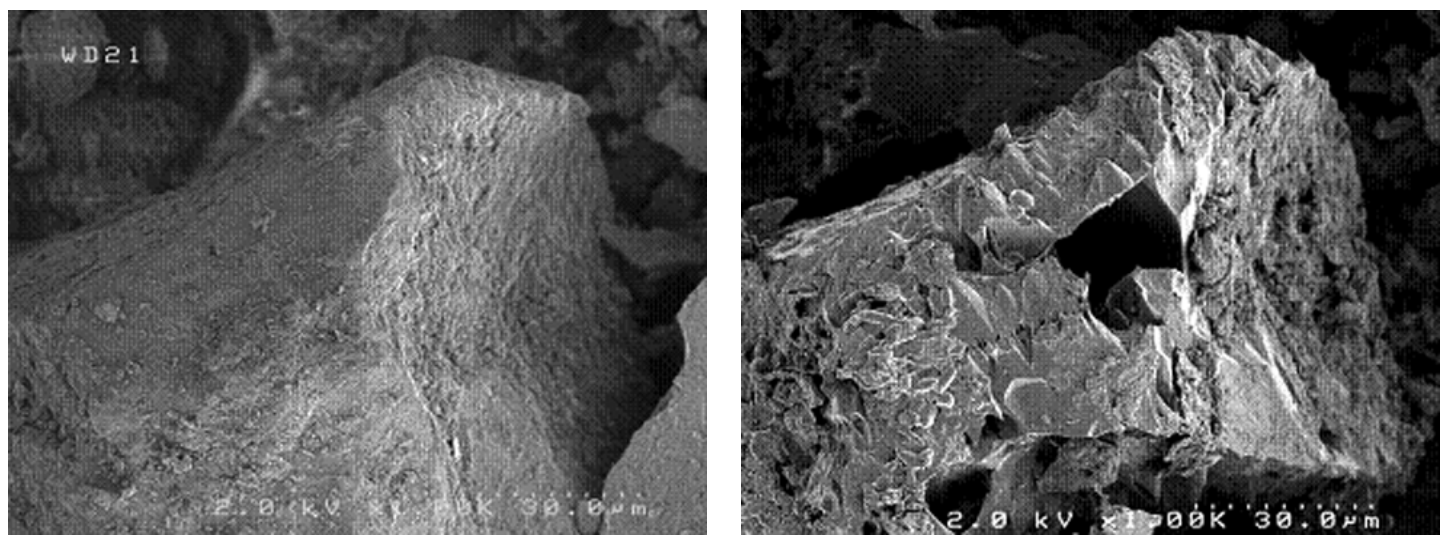

Fig. 2

provide supporting evidence that the microbial pretreatment presence of PR can modify the mineral structure of PR, and in the process, enhance PR dissolution. Further research is necessary to clarify the dissolution pattern of microbiologically-treated PR and the resulting effect on mineralogical properties.

Currently, the use of PSM in a pretreatment process for PR solubilization is being further explored. In theory, optimal acid-producing conditions, should allow for the efficient solubilization of PR. At the University of Guelph, research testing PR solubilization using A. niger is being conducted. First, culture conditions will be optimized for cit- ric acid production using laboratory media. Using these conditions, PR solubilization will be tested when it is: 1) added to the culture media, and 2) reacted with the liquid culture supernatant after acid production has occurred. Once efficient solubilization can be achieved in the laboratory, pot and field trials will be conducted. It is anticipated that this ongoing research will result in advancing the knowledge related to the practical and efficient use of microorganisms to increase the solubility of PR mineral resources.

Significant progress in individual PR solubilization techniques has been made. Combined strate- 
gies, however, will likely provide more optimal conditions for PR use and improve the potential for the application of PR in agriculture. For instance, the combined use of microorganisms, P-extracting plants and mycorrhizal associations, may release a greater amount of $\mathrm{P}$ available for plant uptake. Soil inoculations of mycorrhizal fungi, alone or in combination with other strategies, have been observed to enhance plant uptake of $\mathrm{P}$ (for examples see Barea et al. 2002, Omar 1998, Medina et al. 2005, Toro et al. 1997, Kim et al. 1998). In the future, it is recommended that the integrated use of a number of strategies for increasing $\mathrm{P}$ availability from PR sources continue to be investigated. In addition, agronomic management practices including restoring soil organic matter and coordinating the quantity and timing of liming with PR applications should be encouraged (Chien and Menon 1995). PR field trials are often only conducted over one or two seasons, but in certain conditions, PR utilization by plants has been shown to improve over longer periods of time (Armiger and Fried 1957), indicating the need for more long-term studies. Finally, when conducting greenhouse or field experiments, it is recommended that a relative agronomic effectiveness (RAE) comparison study, with a known conventional phosphate fertilizer, be conducted (Goenadi et al. 2002). Comparing results of a given PR source with a standard reference point allows for the determination of a more useful agronomic effectiveness indicator.

The application of PR as a $\mathrm{P}$ fertilizer has the potential to become widespread once the bioavailability of P from PR sources can be increased to the extent that crop yields and plant tissue $\mathrm{P}$ content are significantly improved. Biological mechanisms of plant and microbial induced PR solubilization represent two innovative solutions for making P from PR more plant-available. Technologies such as these have the potential to enhance dissolution of indigenous sources of PR and transform these resources into more agronomically effective $P$ fertilizers. In a time when intensively produced fertilizers, with undesirable environmental consequences, are likely to become increasingly expensive, low-input, appropriate technologies for restoring and maintaining soil fertility not only make sense, but will be required for sustainable agriculture.

\section{ACKNOWLEDGMENTS}

This work was supported by funding from Natural Sciences and Engineering Research Council of Canada (M.M. Arcand, K.D. Schneider) and from Ontario Ministry of Agriculture and Food New Directions Research Program (M.M. Arcand). Appreciation is expressed to Peter van Straaten, Derek Lynch, and Paul Voroney for critically reviewing the manuscript and contributing supportive comments.

\section{RESUMO}

A deficiência de fósforo disponível nas plantas é considerada o maior fator de limitação na produção de alimentos em diversos solos agrícolas. São necessários recursos minerais para restaurar o conteúdo de fósforo no solo. Em regiões onde fertilizantes convencionais não são utilizados devido às limitações de custo ou de seus efeitos ambientais adversos, fontes locais de rocha fosfática estão sendo crescentemente reconhecidas por seu uso potencial como alternativa aos fertilizantes solúveis de fósforo. O principal obstáculo associado ao uso da aplicação direta da rocha fosfática no solo é que o fósforo liberado é, muitas vezes, incapaz de suprir as necessidades das plantas de forma a aumentar a produção. Mecanismos baseados no uso de plantas e micro-organismos são consideradas tecnologias apropriadas de baixo custo, para ativar a solubilização e aumentar a efetividade agronômica das rochas fosfáticas. Mecanismos comuns de dissolução da rocha fosfática, incluindo a produção de prótons e ácidos orgânicos serão revisados tanto para plantas quanto para microorganismos. Esta revisão também tratará das possibilidades para futuras pesquisas com rochas fosfáticas e suas aplicações na agricultura, assim como destaca pesquisas em andamento na Universidade de Guelph, Canadá.

Palavras-chave: agricultura, microorganismos, rocha fosfática, fósforo, rizosfera, solubilização. 


\section{REFERENCES}

ABD-Alla MH AND OMAR SA. 2001. Survival of rhizobia/bradyrhizobia and a rock-phosphate-solubilizing fungus Aspergillus niger on various carriers from some agro-industrial wastes and their effects on nodulation and growth of faba bean and soybean. J Plant Nutr 24: 261-272.

AGNIHOTRI VP. 1970. Solubilization of insoluble phosphates by some soil fungi isolated from nursery seedbeds. Can J Microbiol 16: 877-880.

Alguacil MM, Caravaca F, Azcon R, Pera J, DiAZ G AND ROLDAN A. 2003. Improvements in soil quality and performance of mycorrhizal Cistus albidus L seedlings resulting from addition of microbially treated sugar beet residue to a degraded semiarid Mediterranean soil. Soil Use Manage 19: 277-283.

ANDERson DL, KRUSSOW WR AND COREY RB. 1985. Phosphate rock dissolution in soil: Indications from plant growth studies. Soil Sci Soc Am J 49: 918-925.

ARMIGER WH AND FRIED M. 1957. The plant availability of various sources of phosphate rock. Soil Sci Soc Am Proc 20: 183-188.

Asea PEA, KuCEy RMN AND Stewart JWB. 1988. Inorganic phosphate solubilization by two Penicillium species in solution culture and soil. Soil Biol Biochem 20: 459-464.

BANIK S AND DEY BK. 1982. Available phosphate content of an alluvial soil as influenced by inoculation of some isolated phosphate-solubilizing microorganisms. Plant Soil 69: 353-364.

Barea JM, Toro M, Orozco MO, Campos E AND AZCON R. 2002. The application of isotopic $\left({ }^{32} \mathrm{P}\right.$ and $\left.{ }^{15} \mathrm{~N}\right)$ dilution techniques to evaluate the interactive effect of phosphate-solubilizing rhizobacteria mycorrhizal fungi and Rhizobium to improve the agronomic efficiency of rock phosphate for legume crops. Nutr Cycl Agroecosys 63: 35-42.

BeEver RE AND Burns DJW. 1980. Phosphorus uptake storage and utilization by fungi Adv Bot Res 8: 127-219.

Bekele T, Cino BJ, Ehlert PAi, van der, MaAs AA AND VAN DIEST A. 1983. An evaluation of plant-borne factors promoting the solubilization of alkaline rock phosphates. Plant Soil 75: 361-378.
BoLAN NS. 1991. A critical review on the role of mycorrhizal fungi in the uptake of phosphorus by plants. Plant Soil 134: 189-207.

Bolan NS, Elliot J, Gregg PEH and Weil S. 1997. Enhanced dissolution of phosphate rocks in the rhizosphere. Biol Fert Soils 24: 169-174.

Brookes PC, POWLSON DS AND JENKINSON DS. 1984. Phosphorus in the soil microbial biomass. Soil Biol Biochem 16: 169-175.

Cavigelli MA and Thien SJ. 2003. Phosphorus bioavailability following incorporation of green manure crops. Soil Sci Soc Am J 67: 1186-1194.

Cerezine PC, Nahas E And Banzatto DA. 1988. Soluble phosphate accumulation by Aspergillus niger from fluorapatite. Appl Microbiol Biotechnol 29: 501-505.

Chien SH ANd Menon RG. 1995. Factors affecting the agronomic effectiveness of phosphate rock for direct application. Fert Res 41: 227-234.

Chien SH, Carmona G, Henao J and Prochnow LI. 2003. Evaluation of rape response to different sources of phosphate rock in an alkaline soil. Comm Soil Sci Plan 34: 1825-1835.

Cole CV, InNis GS and Stewart JWB. 1977. Simulation of phosphorus cycling in semiarid grasslands. Ecology 58: 1-15.

Cunningham JE And Kuiack C. 1992. Production of citric and oxalic acids and solubilization of calcium phosphate by Penicillium bilaii. Appl Environ Microb 58: 1451-1458.

DARRAH PR. 1991. Measuring the diffusion coefficients of rhizosphere exudates in soil. II. The diffusion of sorbing compounds. J Soil Sci 42: 421-434.

Dinkelaker B, Romheld V ANd Marschner H. 1989. Citric acid exudation and precipiation of calcium citrate in the rhizosphere of white lupin (Lupinus albus L). Plant Cell Environ 12: 285-292.

Durand R, Bellon N AND JAILlard B. 2001. Determining the net flux of charge released by maize roots by directly measuring variations of the alkalinity in the nutrient solution. Plant Soil 229: 305-318.

DURO AF AND SERRANO R. 1981. Inhibition of succinate production during yeast fermentation by deenergization of the plasma membrane. Curr Microbiol 6: $111-113$. 
DwIVEdi BS, SINGH VK AND DwIVEDI V. 2004. Application of phosphate rock with or without Aspergillus awamori inoculation to meet phosphorus demands of rice-wheat systems in the Indo-Gangetic plains of India. Aust J Exp Agr 44: 1041-1050

Engelstad OP, Jugsujinda A And De Datta SK. 1974. Response by flooded rice to phosphate rocks of varying citrate solubility. Soil Sci Soc Amer Proc 38: $524-529$.

ENTZ MH, Guilford R AND Gulden R. 2001. Crop yield and soil nutrient status on 14 organic farms in the eastern portion of the northern Great Plains. Can J Plant Sci 81: 351-354.

Flach EN, Quak W and van Diest A. 1987. A comparison of the rock phosphate-mobilizing capacities of various crop species. Trop Agric (Trinidad) 64: 347-352.

Gahoonia TS, ClaAssen N and Albrecht J. 1992. Mobilization of phosphate in different soils by ryegrass supplied with ammonium or nitrate. Plant Soil 140: 241-248.

Gaur AC, Madan M And Ostwal KP. 1973. Solubilization of phosphatic compounds by native microflora of rock phosphates. Indian J Exp Biol 11: $427-429$.

GERKE J. 1992. Phosphate aluminum and iron in the soil solution of three different soils in relation to varying concentrations of citric acid. Z Pflanzenernahr Bodenk 155: 339-343.

GERKE J, ROMER W AND BEIBNER L. 2000. The quantitative effect of chemical phosphate mobilization by carboxylate anions on P uptake by a single root. I. The basic concept and determination of soil parameters. J Plant Nutr Soil Sci 163: 207-212.

Goenadi DH, Siswanto And Sugiarto Y. 2000. Bioactivation of poorly soluble phosphate rocks with a phosphorus-solubilizing fungus. Soil Sci Soc Am J 64: 927-932.

Goenadi DH, Soegiarto Y, Utomo W, Santi LP AND ISROI. 2002. Bio-superphosphate as a new prospecting $\mathrm{P}$ fertilizer for oil palm. International Oil Palm Conference and Exhibition, Bali, Indonesia.

Grewal HS AND KALRA KL. 1995. Fungal production of citric acid. Biotechnol Adv 13: 209-234.

Grinsted MJ, Hedley MJ, White RE and Nye
PH. 1982. Plant-induced changes in the rhizosphere of rape (Brassica napus var Emerald) seedlings. I. $\mathrm{pH}$ change and the increase in $\mathrm{P}$ concentration in the soil solution. New Phytol 91: 19-29.

Gyaneshwar P, Kumar N, Parekh LJ and Poole PS. 2002. Role of soil microorganisms in improving P nutrition of plants. Plant Soil 245: 83-93.

HAYNES RJ. 1992. Relative ability of a range of crop species to use phosphate rock and monocalcium phosphate as $\mathrm{P}$ sources when grown in soil. J Sci Food Agric 60: 205-211.

Hedley MJ, Nye PH And White RE. 1982. Plantinduced changes in the rhizosphere of rape (Brassica napus var Emerald) seedlings New Phytol 91: 44.

HINSINGER P. 2001. Bioavailability of soil inorganic P in the rhizosphere as affected by root-induced chemical changes: A review. Plant Soil 237: 173-195.

Hinsinger P, Plassard C, TANG C AND JAILlard B. 2003. Origins of root-mediated $\mathrm{pH}$ changes in the rhizosphere and their responses to environmental constraints: A review. Plant Soil 248: 43-59.

Hoberg E, Marschner P And Lieberei R. 2005. Organic acid exudation and $\mathrm{pH}$ changes by Gordonia sp and Pseudomonas fluorescens grown with $\mathrm{P}$ adsorbed to goethite. Mic Res 160: 177-187.

HoFFlAND E. 1992. Quantitative evaluation of the role of organic acid exudation in the mobilization of rock phosphate by rape. Plant Soil 140: 279-289.

Hoffland E, Findenegg GR and Nelemans JA. 1989a. Solubilization of rock phosphate by rape. I. Evaluation of the role of the nutrient uptake pattern. Plant Soil 113: 155-16.

Hoffland E, FindenegG GR and Nelemans JA. 1989b. Solubilization of rock phosphate by rape. II. Local root exudation of organic acids as a response to P-starvation. Plant Soil 113: 161-165.

Johnston HW. 1954. The solubilization of "insoluble" phosphate: II - A quantitative and comparative study of the action of selected aliphatic acids on tricalcium phosphate. New Zeal J Sci Tech 36: 49-55.

JONES DL. 1998. Organic acids in the rhizosphere - a critical review. Plant Soil 205: 25-44.

JONES DL AND DARRAH P. 1994. Role of root derived organic acids in the mobilization of nutrients from the rhizosphere. Plant Soil 166: 247-257. 
Jones DL, Dennis PG, OWEN AG AND VAN HeEs PAW. 2003. Organic acid behavior in soils - misconceptions and knowledge gaps. Plant Soil 248: $31-41$.

KARAFFA L AND KUBICEK CP. 2003. Aspergillus niger citric acid accumulation: do we understand this well working black box? Appl Microbiol Biotechnol 61: 189-196.

Kim KY, Jordan D And McDonald GA. 1998. Effect of phosphate-solubilizing bacteria and vesicular-arbuscular mycorrhizae on tomato growth and soil microbial activity. Biol Fertil Soils 26: 79-87.

Konings WN. 1985. Generation of metabolic energy by end-product efflux. Trends Biochem Sci 10: $317-$ 319.

Kpomblekou-A K and Tabatabai MA. 1994. Effect of organic acids on release of phosphorus from phosphate rocks. Soil Sci 158: 442-452.

KUCEY RMN. 1983. Phosphate-solubilizing bacteria and fungi in various cultivated and virgin Alberta soils. Can J Soil Sci 63: 671-678.

KUCEY RMN. 1987. Increased phosphorus uptake by wheat and field beans inoculated with a phosphorus-solubilizing Penicillium bilaji strain and with vesicular-arbuscular mycorrhizal fungi. Appl Environ Microb 53: 2699-2703.

KUCEY RMN. 1988. Effect of Penicillium bilaii on the solubility and uptake of micronutrients from soil by wheat. Can J Soil Sci 68: 261-270.

KuCEY RMN AND LegGetT ME. 1989. Increased yields and phosphorus uptake by Westar Canola (Brassica napus L) inoculated with a phosphatesolubilizing isolate of Penicillium bilaji. Can J Soil Sci 69: 425-432.

KWABiah AB, Palm CA, Stoskopf NC AND VORONEY RP. 2003. Response of soil microbial biomass dynamics to quality of plant materials with emphasis on P availability. Soil Biol Biochem 35: 207-216.

LOES AK AND OGAARD AF. 2001. Long-term changes in extractable soil phosphorus $(\mathrm{P})$ in organic dairy farming systems. Plant Soil 237: 321-332.

Mattey M. 1992. The production of organic acids. Crit Rev Biotechnol 12: 87-132.

MCLENAGHEN RD, RANDHAWA PS, CONDRON LM AND DI HJ. 2004. Increasing phosphate rock avail- ability using a lupin green manure crop. SuperSoil 2004: Proceedings of the $3^{\text {rd }}$ Australian New Zealand Soils Conference, University of Sydney, Australia.

Medina A, VAssilev N, BAREa JM ANd AzCon R. 2005. Application of Aspergillus niger-treated agrowaste residue and Glomus mosseae for improving growth and nutrition of Trifolium repens in a Cdcontaminated soil. J Biotechnol 116: 369-378.

MnKeni PNS, Chien SH ANd CaRmona G. 2000. Effectiveness of Panda Hills phosphate rock compacted with triple superphosphate as source of phosphorus for rape wheat maize and soybean. Commun Soil Sci Plant Anal 31: 3163-3175.

Molla MAZ AND CHOWdhury AA. 1984. Microbial mineralization of organic phosphate in soil. Plant Soil 78: 393-399.

NAhas E, BAnZatTo DA AND Assis LC. 1990. Fluorapatite solubilization by Aspergillus niger in vinasse medium. Soil Biol Biochem 22: 1097-1101.

NARSiAn V AND PATEl HH. 2000. Aspergillus aculeatus as a rock phosphate solubilizer. Soil Biol Biochem 32: 559-565.

Netik A, Torres NV, Riol JM AND KubiceK CP. 1997. Uptake and export of citric acid by Aspergillus niger is reciprocally regulated by manganese ions. Biochim Biophys Acta 1326: 287-294.

Oberson A, Besson JM, MaIRE N AND Sticher H. 1996. Microbiological processes in soil organic transformations in conventional and biological cropping systems. Biol Fertil Soils 21: 138-148.

Oehl F, Oberson A, Tagmann HU, Besson JM, Dubois D, MAder P, Roth H ANd Frossard E. 2002. Phosphorus budget and phosphorus availability in soils under organic and conventional farming. Nut Cyc Agroecosys 62: 25-35.

Oehl F, Frossard E, Fliessbach A, Dubois D AND OBERSON A. 2004. Basal organic phosphorus mineralization in soils under different farming systems. Soil Biol Biochem 36: 667-675.

OMAR SA. 1998. The role of rock-phosphate-solubilizing fungi and vesicular-arbuscular-mycorrhiza VAM) in growth of wheat plants fertilized with rock phosphate. World J Microb Biot 14: 211-218.

Pierzynski GM, Sims JT AND VANCE GF. 1994. Soils and Environmental Quality. Ann Arbor, MI: CRC Press, Inc, 313 p. 
RichaRdSON AE. 2001. Prospects for using soil microorganisms to improve the acquisition of phosphorus by plants. Aust J Plant Physiol 28: 897-906.

Rodriguez H and Fraga R. 1999. Phosphate solubilizing bacteria and their role in plant growth promotion. Biotechnol Adv 17: 319-339.

Rodriguez R, VASSILEV N AND AZCon R. 1999. Increases in growth and nutrient uptake of alfalfa grown in soil amended with microbially-treated sugar beet waste. Appl Soil Ecol 11: 9-15.

Ryan PR, Delhaize E AND RANDALl PJ. 1995. Characterisation of Al-stimulated efflux of malate from the apices of Al-tolerant wheat roots. Planta 196: 103-110.

Sagoe CI, Ando T, Kouno K and Nagaoka T. 1998a. Residual effects of organic acid-treated phosphate rocks on some soil properties and phosphate availability. Soil Sci Plant Nutr 44: 627-634.

Sagoe CI, Ando T, Kouno K and Nagaoka T. 1998b. Relative importance of protons and solution calcium concentration in phosphate rock dissolution by organic acids. Soil Sci Plant Nutr 44: 617-625.

Sale PWG And Mokwunye AU. 1993. Use of phosphate rocks in the tropics. Fert Res 35: 33-45.

Sanchez PA, Shepherd KD, Soule MJ, Place FM, BURESH RJ AND IZAC AN. 1997. Soil fertility replenishment in Africa: an investment in natural resource capital. In: Replenishing soil fertility in Africa, Indianapolis. Proceedings, SSSA Special Publication No. 51, Madison, WI: American Society of Agronomy, 1997, p. 1-46.

SPERBER JI. 1958a. Solution of apatite by soil microorganisms producing organic acids. Aust J Agric Res 9: 782-787.

SPERBER JI. 1958b. The incidence of apatite-solubilizing organisms in the rhizosphere and soil. Aust $\mathbf{J}$ Agric Res 9: 778-781.

Ssali H, AHn P AND MoKwunye A. 1986. Fertility of soils of tropical Africa: a historical perspective. In: Management of Nitrogen and Phosphorus Fertilizers in Sub-Saharan Africa, eds. MoKwUnye AU AND Vlek PLG., Boston: Martinus Nijhoff Publishers, p. 59-82.

STEIN WD. 1967. The movement of molecules across cell membranes. New York: Academic Press, 369 p.
Stewart JWB And TIEssen H. 1987. Dynamics of soil organic phosphorus. Biogeochem 4: 41-60.

SubBA RAO NS. 1999. Soil Microbiology $4^{\text {th }}$ ed., New Hampshire, USA: Science Publishers Inc Enfield, $407 \mathrm{p}$.

Thingstrup I, Kahiluoto H AND JaKOBSEN I. 2000. Phosphate transport by hyphae of field communities of arbuscular mycorrhizal fungi at two levels of P fertilization. Plant Soil 221: 181-187.

TORO M AZCON R AND BAREA JM. 1997. Improvement of arbuscular mycorrhiza development by inoculation of soil with phosphate-solubilizaing rhizobacteria to improve rock phosphate bioavailability $\left({ }^{32} \mathrm{P}\right)$ and nutrient cycling. Appl Environ Micro 63: 4408-4412.

Trolove SN, Hedley MJ, Kirk GJD, Bolan NS And Loganathan P. 2003. Progress in selected areas of rhizosphere research on $\mathrm{P}$ acquisition. Aust J Soil Res 41: 471-499.

VAN RAY B AND VAN DIEST A. 1979. Utilization of phosphate from different sources by six plant species. Plant Soil 51: 577-589.

Van Straaten P. 2002. Rocks for Crops: Agrominerals of sub-Saharan Africa. Nairobi, Kenya: ICRAF, $338 \mathrm{p}$.

Vassilev N, Baca MT, Vassileva M, Franco I AND AzCON R. 1995. Rock phosphate solubilization by Aspergillus niger grown on sugar-beet waste medium. Appl Microbiol Biotechnol 44: 546-549.

VAssilev N, Franco I, VAssileva M and AzCon R. 1996. Improved plant growth with rock phosphate solubilized by Aspergillus niger grown on sugar-beet waste. Bioresource Technol 55: 237-241.

Vassilev N, Vassileva M, Fenice M And FedERICI F. 2001. Immobilized cell technology applied in solubilization of insoluble inorganic rock phosphates and $\mathrm{P}$ plant acquisition. Bioresource Technol 79: $263-271$.

VAssileva M, VAssilev N AND AzCon R. 1998a. Rock phosphate solubilization by Aspergillus niger on olive cake-based medium and its further application in a soil-plant system. World J Microb Biot 14: 281-284.

VASSILEVA M, AZCon R, BAREA JM AND VASSILEV N. 1998b. Application of an encapsulated filamen- 
tous fungus in solubilization of inorganic phosphate. J Biotechnol 63: 67-72.

VORA MS AND SHELAT HN. 1998. Impact of addition of different carbon and nitrogen sources on solubilization of rock phosphate by phosphate-solubilizing micro-organisms. Ind J Agr Sci 68: 292-294.

WEIL RR. 2000. Soil and plant influences on crop response to two African phosphate rocks. Agron J 92: 1167-1175.

Welch SA, Taunton AE and Banfield JF. 2002. Effect of microorganisms and microbial metabolites on apatite dissolution. Geomicrobiol J 19: 343-367.

WHITELAW MA. 2000. Growth promotion of plants inoculated with phosphate-solubilizing fungi. Adv Agron 69: 100-151.

Whitelaw MA, HaRden TJ AND Helyar KR. 1999. Phosphate solubilisation in solution culture by the soil fungus Penicillium radicum. Soil Biol Biochem 31: 655-665.
Widiastuti H, Goenadi DH, PANJi T, SANTi LP, FATURACHIM P, MARDIANA N, HARIANTO I AND ISROI. 2000. Bioactivation of phosphate rocks by indigenous phosphate-solubilizing fungi. Menara Perkebunan 68: 39-52.

Xu R-K, Zhu Y-G And Chittleborough D. 2004. Phosphorus release from phosphate rock and an iron phosphate by low-molecular-weight organic acids. J Environ Sci 16: 5-8.

Zheng SJ, Yang JL, He YF, Yu XH, Zhang L, You JF, SHEN RF AND Matsumoto H. 2005. Immobilization of aluminum with phosphorus in roots is associated with high aluminum resistance in buckwheat. Plant Phys 138: 297-303.

Zhu Y-Q, He Y-G, Smith SE And Smith FA. 2002. Buckwheat (Fagopyrum esculentum Moench) has high capacity to take up phosphorus $(\mathrm{P})$ from a calcium (Ca)-bound sources. Plant Soil 239: 1-8. 